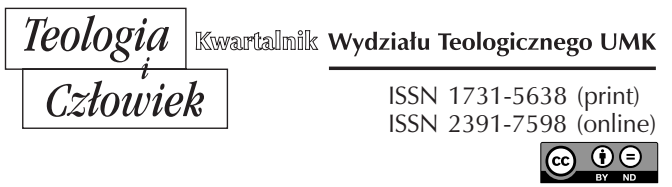

50(2020)2, ss. 239-257

KS. PIOTR PAWEK OCHOTNY

UNIWERSYTET MIKOŁAJA KOPERNIKA W TORUNIU

POCHOTNY@POCZTA.ONET.PL

ORCID 0000-0001-8140-4290

\title{
A THEOLOGY OF THE PARISH
}

DOI: http://dx.doi.org/10.12775/TiCz.2020.026

\begin{abstract}
The parish went through a long path of historical transformations, until it took the shape we know today. It can be the subject of analyses of various scientific disciplines. The aim of this article is to present the theological view of the parish. Indepth theological reflection on the parish reality will be carried out in three points. After presenting the pre-council parish, the theology of the parish will be presented, deduced from the teaching of the Second Vatican Council on particular churches and pre-council teaching of popes. Then, the theological view will be supplemented with a canonical perspective.
\end{abstract}

Keywords: Church; parish; communion; theology; pastoral conversion.

Streszczenie. Teologia parafii. Parafia przeszła długą drogę historycznych przeobrażeń, aż przyjęła kształt, który znamy dzisiaj. Może być przedmiotem analiz różnych dyscyplin naukowych. Celem artykułu jest zaprezentowanie teologicznego ujęcia parafii. Pogłębiona refleksja teologiczna na temat rzeczywistości parafialnej przeprowadzona zostanie w trzech punktach. Po przedstawieniu przedsoborowej wizji parafii (1), ukazania zostanie teologia parafii, wydedukowana $\mathrm{z}$ nauczania Soboru Watykańskiego II o Kościołach partykularnych i posoborowego nauczania papieży (2), a następnie spojrzenie teologiczne uzupełnione zostanie o perspektywę kanoniczną (3).

Słowa kluczowe: Kościół; parafia; wspólnota; teologia; nawrócenie pastoralne. 
The parish went through a long path of historical transformations, until it took the shape we know today. It can be the subject of analyses of various scientific disciplines. From the sociological point of view, the parish is described as a religious community, local community, social group, target group (association), social system or subsystem, community of believers living in a given territory, a social whole united by a specific type of bond, as well as a statistical population or social category. However, the parish is more than just an administrative unit of the Church and a religious and social organism. Above all, it is the Church, and therefore a supernatural reality. The aim of this article is to present the theological view of the parish.

In-depth theological reflection on the parish reality will be carried out in three points. After presenting the pre-council parish, the theology of the parish will be presented, deduced from the teaching of the Second Vatican Council on particular churches and post-council teaching of popes. Then, the theological view will be supplemented with a canonical perspective.

\section{PRE-COUNCIL CHURCH TEACHING ON THE PARISH}

The term "parish" comes from the Latin word parochia, which is

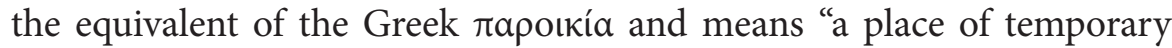
residence" or "people outside their homeland", "people on the move". It

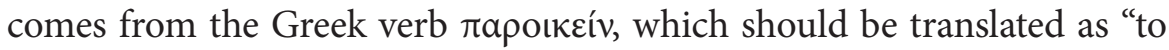
live next door". According to some authors, the noun paroikos meant a "neighbour", especially a stranger, who lived in the city, but without the right of citizenship ${ }^{1}$. All of the above terms contain a spatial element, which is why Karl Rahner believes that the place is the key factor in determining the parish. The Church "incarnates" the specific given place. The principle of the place is, according to him, the first and indestructible foundation of the parish life ${ }^{2}$.

${ }^{1}$ Cf. W. Miziołek, Teologia parafi, in: W Stużbie Ludowi Bożemu, ed. B. Bejze, L. Balter, Poznań-Warszawa 1983, p. 357.

2 Cf. A. Michalik, Duszpasterz wczoraj, dziś i jutro, cz. 2: Wybrane zagadnienia duszpasterskie, Tarnów 1997, pp. 34-35. 
The term זарокко has a similar meaning in the Old Testament. It means a stranger (a foreigner or a nomad) who lives in the land of Israel and enjoys certain privileges but does not have full citizenship rights. This concept was used to emphasize Israel's earthly journey, as opposed to permanent residence in eternity it was heading towards. Hence, the Latin

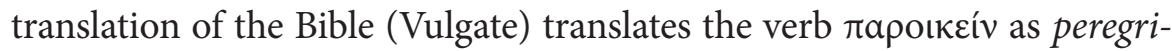
nari, which means: "to be away from homeland", "a stranger", "a foreigner",

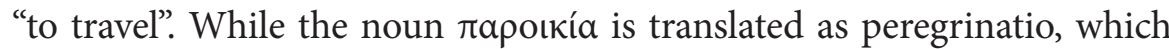
means "wandering", "journey", "pilgrimage"3. The New Testament, followed

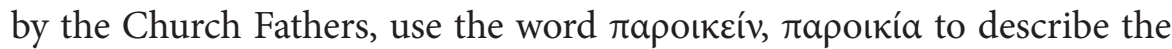
current state of the Church on earth as being abroad as opposed to the permanent and true homeland, that is heaven. St. Peter admonishes the first Christians: "spend your time abroad in fear". However, at the end of the first century, St. Clement of Rome uses the word rapoikía to mean a Church existing in a specific place. Henceforth, rapoikía means the Church existing in a given town, and thus the local Church as opposed to the universal Church ${ }^{4}$.

Initially, the term rapoikía referred to the episcopal church, because in principle there were no other churches. The bishop lived near it with all the clergy, and all religious life and evangelization of a given town or housing estate were also focused around it. At the turn of the third and fourth centuries, titular (auxiliary) churches are being built in large

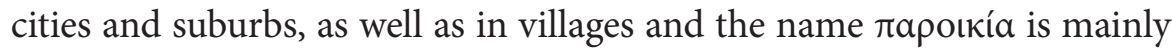
used in relation to them. Priests performed services in them, delegated by the bishop from the presbytery for Sunday and holidays. On some major holidays, the faithful were obliged to gather only in the episcopal church. Over time, the parish churches received their own priests, who stayed near them permanently and performed pastoral activities within the scope entrusted by the bishop and under his control. The growing number of the faithful and the distance of the territories served in converted countries have made the creation of new parishes a pastoral necessity. They received the same rights and duties as episcopal churches, but were always under the jurisdiction of the bishop who was the pastor

${ }^{3}$ Cf. A. Żądło, Parafia w trzecim tysiącleciu, Kielce 1999, pp. 10-11.

${ }^{4}$ Cf. W. Miziołek, Teologia parafii, p. 357. 
of the entire diocese. In the sixth century, the parish system should be considered as well-established in the Church ${ }^{5}$.

The parish in the present sense of the word was founded in the second millennium of the history of the Church and due to the large development of cities. Looking through the collection of decrees of general councils, it can be seen that there are few documents dedicated to the parish and pastoral work carried out there. Almost all conciliar decisions were disciplinary in nature. The first councils dealt primarily with bishops. The Council of Chalcedon spoke about the belonging of the rural parishes to the bishop. The Fifth Lateran Council, which met in 1512-1517, settled the matter of joining the parishes ${ }^{6}$.

Most attention to parish was devoted by the Council of Trent, which took place in 1545-1563. It took into account the reformist demands of many synods from the $15^{\text {th }}$ and $16^{\text {th }}$ centuries, and made some of their provisions universally binding. Convinced of the great religious, social and pastoral importance of the parish, he reformed it in three areas: a) the territory of the parish, church and benefice; b) the rights and obligations of the priest; $\mathrm{c}$ ) the teaching and formation of the clergy. The Council did not work out any new theological treatise about the parish, but made a significant reform in the field of church discipline, renewed the concept of the parish, defined its structure and functions. He perceived the parish more as an institution in which the sacraments are administered, the truths of faith are taught and where the priest is personally responsible for parishioners. Belonging to a parish, according to the Council, should be understood more as belonging to a religious institution than a community. It is defined by the following elements: territory, pastor who knows his parishioners, parish temple and pastoral activities, especially the administration of sacraments ${ }^{7}$.

According to the conciliar documents, the parish was territorial in nature. Living within strictly defined limits was the condition of belonging to it. The council consistently recommended that parishes

${ }^{5}$ Cf. ibidem, p. 358.

${ }^{6}$ Cf. A.L. Szafrański, W poszukiwaniu teologii parafii, „Roczniki Teologiczno-Kanoniczne" 32 (1985) 6, p. 23.

${ }^{7}$ Cf. R. Kamiński, Parafia wspólnota i instytucją. Aspekt historyczny, „Roczniki Teologiczno-Kanoniczne" 32 (1985) 6, p. 30. 
should not extend over too large a territory. The measure of whether the parish has adequate territory is the orderly pastoral care of the faithful and the opportunity to get to know the priest and parishioners directly. In postulating this rule, the Council Fathers were guided by concern for greater protection of the salvation of souls entrusted to the care of the priest. The Council not only required permanent parish boundaries, but also entrusted constant pastoral care to one priest who was to reside in the parish, proclaim the word of God, administer sacraments and take care of the religious education of young people . $^{8}$

The second element determining belonging to a parish is the priest. According to the conciliar teaching, the bishop is the proper pastor of the diocese, responsible for the religious and moral condition of all his diocesans. He is obliged to proclaim the word of God and make sure that it is preached in all parishes. Everything that the Council has said about bishops also applies proportionately to priests who are responsible for pastoral care in the parish. The priest should know his parishioners, and the parishioners should know their priest, because only he can administer certain sacraments in a valid way. If the good of the parishioners so requires, the bishop may appoint, even against the will of the priest, auxiliary clergy to assist him in fulfilling his pastoral ministry ${ }^{9}$.

The third element defining belonging to a parish is the parish temple, constituting the centre of each worship. Its significance, like the parish office, was recognized in the Council's documents. The Council, motivated by concern for the spiritual good of people, in Decretum de reformatione ordered the bishops to increase the number of parishes, so that the faithful could use the sacraments as often as possible. It also recalled the old rule that the faithful often attend their parish churches, at least on Sundays and holidays. However, their duty is to care for church maintenance if traditional incomes would prove insufficient ${ }^{10}$.

The main goal of the Council of Trent was the reorganization of the church's life after the split caused by the reformation. Although the Council Fathers did not deal with the parish in detail, they did develop

${ }^{8}$ Cf. ibidem, p. 31.

${ }^{9}$ Cf. A.L. Szafrański, $W$ poszukiwaniu teologii parafii, pp. 23-24.

${ }^{10}$ Cf. ibidem, p. 23. 
some general, albeit important for the functioning of the parish norms, leaving bishops the opportunity for the reformative action. These norms consolidated and strengthened the parish organization, as well as the pastoral work implemented in it as follows: all parishes, both in cities and in villages, were to have strict boundaries as well as their own and permanent pastors; in the case of large parishes, especially municipal ones, one or more priests had to be assigned in addition to the pastor to assist him in parish pastoral care; in the case of large parishes, they had to be divided into smaller parishes to enable the faithful to get to know their own pastor, contact their own parish church and follow religious practices; in the case of newly erected parishes, it was necessary to provide funds for their establishment by obtaining the parish benefice's salary and the offerings of the faithful. The Council also raised the issue of how to appoint parish priests, gather the resources they need for daily maintenance and the basic duties of pastors. Among the latter, attention was drawn to the need to catechise and preach the word of God, administer the sacraments, exemplary life and residing in the parish ${ }^{11}$.

In the first half of the $20^{\text {th }}$ century, it became increasingly clear that the legal and administrative understanding of the parish depletes its importance as a community in the supernatural order and as a centre of liturgical and religious life. This approach was strongly influenced by the teaching of popes from the turn of the $19^{\text {th }}$ and $20^{\text {th }}$ centuries, especially Leo XIII, Pius X and Pius XI. It is worth paying attention to the letter of Pope Benedict XV of April 14, 1917 to bishop Landrieux, praising his pastoral letter about the renewal of parish life. Regretting the disappearance of family life in the parish, the Pope draws attention to the need to return to the old tradition. In turn, pope Pius XII in a speech to Lenten preachers in 1946 emphasized that the life force of the Church is manifested mainly in direct pastoral care at the altar, in the pulpit, in the confessional, at the bed of the sick, in catechesis and in personal teaching. The purpose of pastoral care is supernatural life, guaranteeing dignity, happiness and order in human society. Achieving this goal is possible directly in the parish community. The schools is not in the centre of the parish, but the temple with a tabernacle and a confessional, which is a sign of the unity

${ }^{11}$ Cf. A. Żądło, Parafia w trzecim tysiącleciu, pp. 25-26. 
of God and people. Parish life makes it possible to get to know Jesus, to love him and to serve him. Everything else should serve this proper task. The pastor is a servant of the People of God and a secretor, especially of the Eucharist, at which table the faithful gather ${ }^{12}$.

\section{THE TEACHING OF THE SECOND VATICAN COUNCIL ON PARTICULAR CHURCHES AND POST-COUNCIL TEACHING OF POPES}

The Second Vatican Council, although it did not comment on the organizational structure of the parish, nevertheless it developed new theological assumptions on the basis of which it is possible to better understand the nature and basic mission of the parish, which through it fulfils the Christ Church in a specific environment. The teaching of the Second Vatican Council regarding the parish is related to the theology of the local Church. The Council recalled and developed the theology of the local Church, well preserved in the tradition of the Eastern Church, in dogmatic constitution on the Church Lumen gentium. The universal Church exists in the local Church and is a community of these Churches. The most important statement regarding the theology of the local Church is found in number 26: "This Church of Christ is truly present in all legitimate local congregations of the faithful which, united with their pastors, are themselves called Churches in the New Testament"13. It indicates the two-level criterion of ecclesiality: (1) "legitimate local congregations of the faithful" meaning eucharistic community and (2) "united with their pastors". This means that a simple liturgical act in the right place is not enough to create the Church, but the principle of integration "around the bishop" is always required ${ }^{14}$.

The ecclesiology of the local Church is also clearly visible in number 28, which shows the parish, directed by priests on behalf of the bishops, as a local Church, which is the sign of the universal Church:

${ }^{12}$ Cf. A.L. Szafrański, W poszukiwaniu teologii parafii, pp. 24-25.

${ }^{13}$ Second Vatican Council, The Dogmatic Constitution on the Church Lumen gentium (LG), 26.

${ }^{14}$ Cf. J. Ratzinger, Kościót - ekumenizm - polityka, tłum. L. Balter, Poznań-Warszawa 1990, pp. 18-19. 
Priests, prudent cooperators with the Episcopal order, its aid and instrument, called to serve the people of God, constitute one priesthood with their bishop although bound by a diversity of duties. Associated with their bishop in a spirit of trust and generosity, they make him present in a certain sense in the individual local congregations, and take upon themselves, as far as they are able, his duties and the burden of his care, and discharge them with a daily interest. And as they sanctify and govern under the bishop's authority, that part of the Lord's flock entrusted to them they make the universal Church visible in their own locality and bring an efficacious assistance to the building up of the whole body of Christ $^{15}$.

In the light of the above Council statements, there is no doubt that the parish is part of the Church in its diocesan structure. The diocese has the fullness of supernatural life and means of salvation as the local Church, i.e. the community of believers living in a specific place, entrusted to the pastoral care of the diocesan bishop. In its existence, the parish depends on the diocese, participates in its life and can be fully understood only in connection with the diocese ${ }^{16}$. However, it is not only the smallest cell of the hierarchically built Church, but also the Church of God and God's new People called by God. The Council, calling the parish the Church of God, does so not in direct form, as was the case with the diocese, but indirect form: "pastors let them so lead and serve their local community that it may worthily be called by that name, by which the one and entire people of God is signed, namely, the Church of God"17.

The existence and functioning of the parish within the diocese ensures its effectiveness of representing the mystery of the Church and its attributes to the believers. Many theological features that relate to the Church also apply to parishes. The parish participates in the attributes of the Church, which is one, holy, universal and apostolic. The unity of the parish lies in its relationship with the Mystical Body of Christ and his visible Head. This indicates not only the unity of supreme power, the unity of faith and the sacraments, but also the bond between pastors and parishioners. The sanctity of the parish is expressed, above all, by the pres-

15 LG 28.

${ }^{16}$ Cf. W. Miziołek, Teologia parafi, p. 360.

17 LG 28. 
ence of the believers living in a state of sanctifying grace. The catholicity of the parish indicates its communion with the Church. The universalism of the Church in parish life demands interest in its fate and orders the support for missionary and ecumenical activity. In contrast, the parish participates in the apostolate of the Church through its relationship with the bishop and pope, by professing the same faith, receiving the same sacraments and preaching the Word of God ${ }^{18}$.

The documents of the Second Vatican Council emphasize that the parish is the final location of the Church. Its saving and sanctifying activity is taking place in the parish. The constitution of the Sacred Liturgy Sacrosanctum concilium states: "But because it is impossible for the bishop always and everywhere to preside over the whole flock in his Church, he cannot do other than establish lesser groupings of the faithful. Among these the parishes, set up locally under a pastor who takes the place of the bishop, are the most important: for in some manner they represent the visible Church constituted throughout the world"19. The Parish presents, i.e. makes present the "visible Church constituted throughout the world". It is not only the result of a progressive process consisting in the birth of new, smaller church organisms, but first and foremost the highest degree of the Church's actualization and realization. In the most tangible and intense way, the Church accomplishes, by celebrating the Eucharist in communion with the bishop by a priest for a specific, relatively stable group of the faithful ${ }^{20}$.

The diocese and parish are built on the same foundations that underpin the original Christian community and continue to maintain this community, i.e. on God's word, the sacraments and the service love. However, it is worth making a note here. The parish, theologically speaking, does not have its own specific existence, because the diocese was dogmatically and historically more primitive than it. It is the diocese that, because of its bishop as successor of the apostles leading its way, comes

${ }^{18}$ Cf. R. Kamiński, Duszpasterstwo w społeczeństwie pluralistycznym, Lublin 1997, p. 64.

19 Second Vatican Council, The Constitution on the Sacred Liturgy Sacrosanctum Concilium (SC), 13.

${ }^{20}$ Cf. W. Miziołek, Teologia parafii, p. 362; See A. Perzyński, Parafia w świetle teologii Kościoła lokalnego, in: Dziś i jutro parafii, ed. A. Lepa, Łódź 1991, p. 56. 
from God's appointment, while the parish was established in certain historical conditions and undergoes historical changes. The Council admits its ecclesial character, but it is different from the ecclesiality of the diocese. Thus, parishes are not, like dioceses, a local Church in the full sense of the word. They are it in the sense of hierarchical subordination. This reveals the conciliar definition of a parish as a specific part of the diocese ${ }^{21}$, as if its cell"2, which "represents the visible Church in some way"23.

The views of John Paul II on the parish are largely based on the ecclesiology of the Second Vatican Council. He included them in a basic study on the implementation of the conciliar resolutions, in which he repeatedly refers to the parish as an established institution of the Church ${ }^{24}$. In the apostolic exhortation Christifideles laici in number 26 it states that: "the ecclesial community, while always having a universal dimension, finds its most immediate and visible expression in the parish. It is there that the Church is seen locally. In a certain sense it is the Church living in the midst of the homes of her sons and daughters". Among the many definitions of the parish of a doctrinal and pastoral nature, the definition of a parish as a community is particularly close to the Pope, based on the central and basic ecclesiological idea of Vaticanum II, that is communio. According to his teaching, the parish "is not principally a structure, a territory, or a building, but rather, «the family of God, a fellowship afire with a unifying spirit», «a familial and welcoming home», the «community of the faithful»"25.

The parish as a community is an organic unity, analogous to the unity of a alive and efficient body, which is why numerous vocations and charisms co-exist in it, which, despite the differences, are complementary to each other, which is emphasized by John Paul II in exhortation Christifideles laici in no. 20, referring to the famous fragment of the 1 Letter

${ }^{21}$ Cf. Second Vatican Council, Decree on the Pastoral Ministry of Bishops Christus Dominus (CD), 30.

${ }^{22}$ Cf. Second Vatican Council, Decree on the apostolate of the laity Apostolicam actuositatem, 10.

${ }^{23} \mathrm{SC} 42$.

${ }^{24}$ See K. Wojtyła, U podstaw odnowy. Studium o realizacji Vaticanum II, Kraków 2003.

${ }^{25}$ John Paul II, Apostolic exhortation Christifideles laici (ChL), 26. 
to the Corinthians, in which the Apostle of the Nations states explicitly: "For we were all baptized by one Spirit so as to form one body [...] As it is, there are many parts, but one body" (1 Cor 12,13-26). The parish community consists of all its members who believe in Christ. An important role in this community is played by the priest, who is the hierarchical link connecting the parish with the particular Church. The parish united in Christ creates an environment built on paschal mystery. The Church is located in it. John Paul II explains that the parish is the local and closest realization of the mystery of Church to every Christian ${ }^{26}$.

The Pope also emphasizes the role of the Eucharist in building a parish community. He describes the parish as a Eucharistic community in which the Eucharist is constantly celebrated, being a source of community growth and a sacramental node of communion of the whole Church. From the bloodless sacrifice of Christ, the parish draws a special power by which it becomes a spiritual community ${ }^{27}$. At the same time the parish community is built through service love. It is in the parish that the active love of neighbour can be realized in a specific and direct manner. Aware of the challenges that the parishes face in the secularized world, the Pope emphasizes their necessity for the life of the Church and the community-forming nature: "Whatever one may think, the parish is still a major point of reference for the Christian people, even for the non-practicing" ${ }^{28}$.

Pope Francis also draws attention to the role of the parish in pastoral care and the need to renew it. He embeds the parish's issues in the natural human context, emphasizing at the same time its spiritual and theological character. In the spirit of ecclesiology of communion, he states that:

The parish is the presence of the Church in a given territory, an environment for hearing God's word, for growth in the Christian life, for dialogue, proclamation, charitable outreach, worship and celebration.

${ }^{26}$ Cf. John Paul II, Apostolic exhortation Pastores dabo vobis, 68.

27 See Idem, Parafia - wspólnota wiary, nadziei i miłości. Przemówienie do księży $i$ zaangażowanych $w$ prace duszpasterska (Ultrecht, 12.05.1985), in: Dzieła zebrane, t. 10: Homilie i przemówienia z pielgrzymek - Europa, Kraków 2008, pp. 725-729.

${ }^{28}$ Idem, Apostolic exhortation Catechesi tradendae, 67. 
In all its activities the parish encourages and trains its members to be evangelizers. It is a community of communities, a sanctuary where the thirsty come to drink in the midst of their journey, and a centre of constant missionary outreach ${ }^{29}$.

According to Francis, the Church is a community "on the road", i.e. constantly renewed by Jesus Christ. This also applies to its structures. In his teaching, the Pope confirms the importance of the parish as an extremely vital structure, but at the same time postulates that everything that happens in the Church, and therefore also at the parish level, should be more missionary, open and lead people to commitment and service in the work of evangelization. In the exhortation Evangelii gaudium in number 28, he emphasizes:

The parish is not an outdated institution; precisely because it possesses great flexibility, it can assume quite different contours depending on the openness and missionary creativity of the pastor and the community $[\ldots]$ This presumes that it really is in contact with the homes and the lives of its people, and does not become a useless structure out of touch with people or a self-absorbed group made up of a chosen few ${ }^{30}$.

The above words are in line with the papal call to the whole Church for pastoral conversion and missionary pastoral ministry, which seeks to abandon the complacent attitude that says: «We have always done it this way» ${ }^{31}$, breaking down common patterns of action and changing thinking. The constant ability to reform the parish protects this community against ossification and heaviness. The relevance of this call is evidenced by Francis' realistic look at the condition of the modern parish: "We must admit, though, that the call to review and renew our parishes has not yet sufficed to bring them nearer to people, to make them environments of living communion and participation, and to make them completely mission-oriented"32.

\footnotetext{
${ }^{29}$ Francis, Apostolic exhortation Evangelii gaudium (EG), 28.

${ }^{30}$ EG 28.

31 Ibidem, 33.

${ }^{32}$ Ibidem, 28.
} 
He also notes with sadness that the unfriendly structures of parishes and communities, the bureaucratic approach to ordinary and complex problems of people and the climate prevailing in them means that some baptized people do not experience their belonging to the Church. In addition, he points out that in many places, the "administrative aspect prevails over the pastoral aspect", and that the administration of the sacraments takes place without other forms of evangelization:

We must recognize that if part of our baptized people lack a sense of belonging to the Church, this is also due to certain structures and the occasionally unwelcoming atmosphere of some of our parishes and communities, or to a bureaucratic way of dealing with problems, be they simple or complex, in the lives of our people. In many places an administrative approach prevails over a pastoral approach, as does a concentration on administering the sacraments apart from other forms of evangelization ${ }^{33}$.

\section{THE PARISH IN CANON LAW}

The Code of Canon Law of 1917 defined the parish as a separate part of the territory of the diocese with its own church, its own people and own priest, who ex officio performs his ministry there ${ }^{34}$. The canonical definition strongly emphasized the relationship of the parish with the particular Church, as well as its territorial character. In the light of the provisions of the Code, each part of the territorial diocese, which is a parish, should appoint a special church with a certain number of the faithful and their own shepherd in order to provide the necessary care of the souls. However, this definition does not mention what a parish is in the body of the Church and what role it should play in it. This problem was noticed only by the Second Vatican Council ${ }^{35}$. The Old Code of the Canon Law repeated the definition of the parish, the rights and duties of parish priest according to the Council of Trent, focusing on the visible (external) aspect of the parish. According to can. 216, the parish consists of the following elements: (1) Territory - a place determined by the bishop. This is a very important ele-

${ }^{33}$ Ibidem, 63.

${ }^{34}$ Cf. The Code of Canon Law of 1917 (CIC/17), can. $216 \$ 1$.

${ }^{35}$ See R. Kamiński, Parafia wspólnota i instytucja, pp. 33-34. 
ment, because it underlies the principle of parish territoriality, excluding the creation of, e.g. parishes related to a person or a group of people. A community without a specific place in a physical and geographical sense can easily be dispersed. The visible territory also allows management stability. (2) Permanent priest - a visible Shepherd standing at the head of the parish. In his ministry, it is not enough to just lead. Above all, there is the need of management. You can preside over a community, but not lead it. (3) Visible and specific God's people (populus determinatus) - a certain number of the faithful living in a given territory. None of the residents can be deprived of pastoral care. Even the non-Catholics living in their territory should be kept in mind and looked after. (4) Church - a visible building, which is a sign of unity and centre of the parish. An official worship takes place in it, people can gather in it to listen to the Word of God and make sacrifices to God. This is also where the impulses for apostolic action come from ${ }^{36}$.

The 1983 Code of Canon Law, based on the dogmatic Constitution on the Church Lumen gentium and other documents of the Second Vatican Council, defines the parish as follows: "A parish is a certain community of the Christian faithful stably constituted in a particular church, whose pastoral care is entrusted to a pastor (parochus) as its proper pastor (pastor) under the authority of the diocesan bishop" ${ }^{37}$. The legislator defines the parish as a specific community of faithful Christians that is part of the particular Church ${ }^{38}$. The new approach clearly departs from the juridical concept of the parish, which treated the parish as an administrative unit of the diocese, to the theological concept of the parish, postulated by the Second Vatican Council, which exposes a specific community of believers ${ }^{39}$. All baptized belong to it, according to the applicable law ${ }^{40}$, but only those "who are joined with Christ in its visible structure

${ }^{36}$ Cf. R. Rak, Parafia - wspólnota i parafia - instytucja. Aspekt pastoralny, „Roczniki Teologiczno-Kanoniczne" 32 (1985) 6, p. 42.

37 The Code of Canon Law of 1983 (CIC/83), can. $515 \$ 1$.

${ }^{38}$ Cf. J. Krukowski, Rozdział VI. Parafie, proboszczowie i wikariusze parafialni, in: Komentarz do Kodeksu Prawa Kanonicznego. Księga II. Lud Boży. Część I. Wierni chrześcijanie. Czesść II. Ustrój hierarchiczny Kościoła, ed. J. Krukowski, t. 2/1, Poznań 2005, p. 411.

${ }^{39}$ Cf. SC 42.

${ }^{40}$ Cf. CIC/83, can. 204. 
by the bonds of the profession of faith, the sacraments, and ecclesiastical governance"41 remain in full communion with the Church.

"As a general rule a parish is to be territorial, that is, one which includes all the Christian faithful of a certain territory" 42 . However, the Code allows for the possibility of establishing personal parishes for the sake of the spiritual good of specific groups of the faithful, creating a homogenous community of people of the same nationality, language, rite, etc. The diocesan bishop may, after consulting the presbyteral council, erect new parishes wherever this is supported by the pastoral needs ${ }^{43}$. The legislator also indicates the possibility of creating a temporary parish wherever there are no conditions to establish a canonical parish ${ }^{44}$. In difficult pastoral situations, when the parish is unable to meet the spiritual needs of the faithful, the current Code of Canon Law indicates the creation of appropriate replacement or supplementary structures, e.g. parish associations, which, while maintaining their identity, support themselves pastorally ${ }^{45}$, dividing parishes into smaller districts, incorporated into the home parish, establishing auxiliary pastoral centres ${ }^{46}$, and above all, interparish and supra-parish cooperation, developed at the deanery level or at the higher level of pastoral organization in the diocese ${ }^{47}$.

The parish is a community of the People of God associated with the diocese and the diocesan bishop who is represented by the parish priest ${ }^{48}$. On behalf of the bishop and in connection with him, he proclaims the word of God, administers the holy sacraments and takes responsibility for managing the parish. "As pastors in their own name they are entrusted with the care of souls in a certain part of the diocese under the bishop's authority" ${ }^{49}$. The Code defines the pastor as follows:

\footnotetext{
${ }^{41}$ Ibidem, can. 205.

42 Ibidem, can. 518.

${ }^{43}$ Cf. ibidem, can. $515 \$ 2$.

${ }^{44}$ Cf. ibidem, can. $516 \S 2$.

${ }^{45}$ Cf. ibidem, can. $517 \$ 1-2$.

${ }^{46}$ Cf. ibidem, can. 568

47 Cf. ibidem, can. 553-555.

${ }^{48}$ Cf. SC 42.

${ }^{49} \mathrm{CD} 30$.
} 
The pastor (parochus) is the proper pastor (pastor) of the parish entrusted to him, exercising the pastoral care of the community committed to him under the authority of the diocesan bishop in whose ministry of Christ he has been called to share, so that for that same community he carries out the functions of teaching, sanctifying, and governing, also with the cooperation of other presbyters or deacons and with the assistance of lay members of the Christian faithful, according to the norm of law ${ }^{50}$.

The word "own" exposes the priest's personal and close relationship with the parish. This definition of the priest, based on the teaching of the Second Vatican Council, differs in its theological aspect from the definition included in the previously applicable law ${ }^{51}$. The priest is not a cum cura animarum beneficiary, but above all, a shepherd of the faithful entrusted to him, participating in the mission of teaching, sanctifying and ruling. According to the applicable law, the priest's associates in his service are, first of all, presbyters, especially parish vicars, as well as lay faithful, performing some offices and services in accordance with the law ${ }^{52}$.

The evolution of the concept of the parish can be clearly seen from the Code of Canon Law of 1917 to the currently applicable church law. The previous Code did not directly define the concept of a parish. It could be deducted from the normative regulation, contained in canon 216, on the need to divide the diocese into separate territorial parts. According to this regulation: "The territory of every diocese is to be divided up into distinct territorial parts; to each part a specific church and determined population are assigned, with its own rector as its pastor, who is over

${ }^{50} \mathrm{CIC} / 83$, can. 519.

${ }^{51}$ For comparison, the Code of Canon Law of 1917 defined the concept of a pastor as follows: "Parochus est sacerdos vel persona moralis cui paroecia collata est in titulum cum cura animarum sub Ordinarii loci auctoritate exercenda" (CIC/17, can. 451 $\$ 1$ ). Own translation: "The pastor is a priest (or a moral person), who is permanently entrusted with the title of a parish with the obligation to exercise pastoral care on his behalf, depending on the local ordinary". A thorough discussion of the above canon can be found in: S. Biskupski, Stanowisko proboszcza w świetle prawa kanonicznego, Płock 1966, pp. 12-17.

${ }^{52}$ Cf. T. Pawluk, Prawo kanoniczne według Kodeksu Jana Pawła II. Lud Boży jego nauczanie i uświęcanie, t. 2, Olsztyn 2002, p. 237. 
it for the necessary care of souls"53. The teaching of the Second Vatican Council on the subject of the parish shifts the focus from the territorial element, exposed in the 1917 Code, to the personal element, defining the parish as part of the diocese ${ }^{54}$, a group of the faithful, organized locally under the leadership of a priest, replacing the bishop ${ }^{55}$, God's people ${ }^{56}$. This is the line that the 1983 Code followed, according to which the essential elements of the parish are: a specific community of the faithful, its close relationship with the particular Church, the bishop's authority towards the community and the pastor's office. The above definition of the parish, contrary to the definition of the 1917 Code, ignores the territorial element. In the canonical description of the parish, first of all, the community of the People of God is exposed, associated with the diocese and bishop. The presence of the priest, who is to unite and activate the community of the People of God, and coordinate its activities, is a very important element of the parish.

The main purpose of this article was to present the theological view of the parish. The conducted analyses made it possible to define the parish as part of the local Church in the diocesan structure, over which the pastoral care, under the authority of the diocesan bishop, is entrusted to the priest as its own shepherd. The parish has always been considered not only a part of the diocese, closely related to the universal Church, but also as a meeting place, the mission of the whole Church with the faith of individuals, families and small communities. It was treated as the most advanced outpost of the Church in its contact with the world. The aspect of the parish's directness and its relationship with the place is the specificity of this community. The parish lives and works, being a community firmly embedded in the local community and built on similar but always unique environmental factors. This makes each parish different, although each one represents the Church in a concrete and "tangible" way.

${ }^{53} \mathrm{CIC} / 17$, can. $216 \S 1$.

${ }^{54}$ Cf. CD 30.

${ }^{55}$ Cf. SC 42.

${ }^{56}$ Cf. LG 28. 


\section{BIBLIOGRAPHY}

Benedict XV, Codex Iuris Canonici (27.05.1917), “Acta Apostolicae Sedis" 9/II(1917), pp. 2-593.

Biskupski S., Stanowisko proboszcza w świetle prawa kanonicznego, Płock 1966.

Francis, Apostolic exhortation Evangelii gaudium, Poznań 2014.

John Paul II, Apostolic exhortation Catechesi tradendae, in: idem, Dzieła zebrane, t. 2: Adhortacje, Kraków 2006, pp. 17-62.

John Paul II, Apostolic exhortation Pastores dabo vobis, in: idem, Dzieła zebrane, t. 2: Adhortacje, pp. 325-417.

John Paul II, Apostolic exhortation Christifideles laici, in: idem, Dzieła zebrane, t. 2: Adhortacje, pp. 219-294.

John Paul II, Kodeks Prawa Kanonicznego, Poznań 2008.

John Paul II, Parafia - wspólnota wiary, nadziei i miłości. Przemówienie do księży i zaangażowanych w pracę duszpasterska (Ultrecht, 12.05.1985), in: idem, Dzieła zebrane, t. 10: Homilie i przemówienia z pielgrzymek - Europa, Kraków 2008, pp. 725-729.

Kamiński R., Duszpasterstwo w społeczeństwie pluralistycznym, Lublin 1997.

Kamiński R., Parafia wspólnota i instytucją. Aspekt historyczny, „Roczniki Teologiczno-Kanoniczne” 32 (1985) 6, pp. 15-35.

Krukowski J., Rozdział VI. Parafie, proboszczowie i wikariusze parafialni, in: Komentarz do Kodeksu Prawa Kanonicznego. Księga II. Lud Boży. Część I. Wierni chrześcijanie. Część II. Ustrój hierarchiczny Kościoła, ed. J. Krukowski, t. 2/1, Poznań 2005, pp. 409-563.

Michalik A., Duszpasterz wczoraj, dziś i jutro, cz. 2: Wybrane zagadnienia duszpasterskie, Tarnów 1997.

Miziołek W., Teologia parafi, in: W Stużbie Ludowi Bożemu, ed. B. Bejze, L. Balter, Poznań-Warszawa 1983, pp. 357-366.

Pawluk T., Prawo kanoniczne według Kodeksu Jana Pawła II. Lud Boży jego nauczanie i uświęcanie, t. 2, Olsztyn 2002.

Perzyński A., Parafia w świetle teologii Kościoła lokalnego, in: Dziś i jutro parafii, ed. A. Lepa, Łódź 1991, pp. 47-74.

Rak R., Parafia - wspólnota i parafia - instytucja. Aspekt pastoralny, „Roczniki Teologiczno-Kanoniczne" 32 (1985) 6, pp. 37-49.

Ratzinger J., Kościół - ekumenizm - polityka, tłum. L. Balter, Poznań-Warszawa 1990.

Second Vatican Council, Decree on the apostolate of the laity Apostolicam actuositatem, in: Konstytucje, dekrety, deklaracje, Poznań 2002, pp. 377-401.

Second Vatican Council, Decree on the Pastoral Ministry of Bishops Christus Dominus, in: Konstytucje, dekrety, deklaracje, pp. 236-258.

Second Vatican Council, The Constitution on the Sacred Liturgy Sacrosanctum Concilium, in: Konstytucje, dekrety, deklaracje, pp. 48-78.

Second Vatican Council, The Dogmatic Constitution on the Church Lumen gentium, in: Konstytucje, dekrety, deklaracje, pp. 104-166. 
Szafrański A.L., W poszukiwaniu teologii parafii, „Roczniki Teologiczno-Kanoniczne” 32 (1985) 6, pp. 21-41.

Wojtyła K., U podstaw odnowy. Studium o realizacji Vaticanum II, Kraków 2003.

Żądło A., Parafia w trzecim tysiącleciu, Kielce 1999. 